GLOBALIZATION, CONVERGENCE, AND HISTORY

Jeffrey G. Williamson

Working Paper 5259 
NBER WORKING PAPER SERIES

\section{GLOBALIZATION, CONVERGENCE, AND HISTORY}

Jeffrey G. Williamson

Working Paper 5259

\section{NATIONAL BUREAU OF ECONOMIC RESEARCH 1050 Massachusetts Avenue \\ Cambridge, MA 02138 \\ September 1995}

An abridged version of this paper was delivered as the Presidential Address to the Economic History Association, Chicago, (September 8-10, 1995). The research has been supported since 1990 by National Science Foundation grants SES-90-21951 and SBR-92-23002 for which I am grateful. I am also grateful for the excellent research assistance (and insightful comments) of Bill Collins. In addition, I want to thank my collaborators Tim Hatton, Kevin O'Rourke and Alan Taylor with whom I have shared so many of the discoveries surveyed in this paper. They, Moe Abramovitz, Mike Edelstein, Anne Krueger and Jeff Sachs have all offered advice which has greatly improved the final product. This paper is part of NBER's research program in the Development of the American Economy. Any opinions expressed are those of the author and not those of the National Bureau of Economic Research.

(C) 1995 by Jeffrey G. Williamson. All rights reserved. Short sections of text, not to exceed two paragraphs, may be quoted without explicit permission provided that full credit, including () notice, is given to the source. 


\title{
GLOBALIZATION, CONVERGENCE, AND HISTORY
}

\begin{abstract}
There were three epochs of growth experience after the mid 19th century for what is now called the OECD "club"; the late 19th century, the middle years between 1914 and 1950, and the late 20th century. The late 19 th and the late 20th century epochs were ones of overall fast growth and convergence: poor countries tended to grow even faster than rich and the economic gap between rich and poor countries diminished. The middle years were ones of overall slow growth and divergence: poor countries tended to grow even slower than rich and the economic gap between rich and poor countries widened. Since the middle years were also ones of economic autarky and "de-globalization", while the rest were ones of increasing globalization in world commodity and factor markets, history offers an unambiguous positive correlation between globalization and convergence. But is the correlation spurious? When the pre-World War I years are examined in detail, the correlation turns out to be causal: the globalization of commodity and factor markets served to play a critical, perhaps the critical, role in contributing to convergence. A century and a half of OECD club history also suggests that economists should pay more attention to who gains and who loses from convergence since the answers may help determine whether pro-globalization or anti-globalization policies will persist.
\end{abstract}

Jeffrey G. Williamson

Department of Economics

216 Littauer Center

Harvard University

Cambridge, MA 02138

and NBER 


\section{Theory Needs History}

Two important features of the late 20th century international economy characterized the late 19th century as well. First, the earlier period was one of rapid globalization: capital and labor flowed across national frontiers in unprecedented quantities, and commodity trade boomed as transport costs declined sharply. second, the late 19th century underwent an impressive convergence in living standards, at least within most of what we would now call the OECD club. Poor countries at the periphery of the European club tended to grow faster than the rich industrial leaders at the center of the Old World, and often even faster than the richer countries overseas in the New World. This club excluded, of course, most of the Third World and eastern Europe, and even around this limited periphery there were some who failed to catch up. But while spain and Portugal lagged behind the leaders, others -like Ireland, Italy, and the scandinavian countries -- underwent a spectacular catch-up from the Great Famine to the Great War. To what extent were globalization and convergence connected?

I will argue that most of the convergence between 1850 and 1914 was due to the open economy forces of trade and mass migration. I will by inference also suggest that convergence stopped between 1914 and 1950 because of deglobalization and implosion into autarchy.

I start with the convergence evidence and then offer the open economy explanations for it.

\section{Convergence in the Past}

What does history have to say about convergence? To answer that question, we have to agree on the meaning of convergence. The critical bottom line for me is whether the living standard gap between rich and poor countries falls over time. Convergence implies an erosion in this gap, at least in percentage terms. New growth theorists call this sigma-convergence. To get 
gigma-convergence, poor countries must grow faster than rich, an event new growth theorists call beta-convergence. Second, what history? My interest has always been in what simon Kuznets called modern economic growth, and that translates here into the century and a half gince about 1850. Third, convergence of what? There appear to be two data sets that can be used for such analysis. Angus Maddison'g GDP per worker-hour estimates offer one (originally published in 1982, now supergeded by his 1991 book and by even more recent revisions). My real wages of the urban unskilled offer another (purchasing-power-parity adjusted: Williamson 1995). Fourth, convergence among whom? As the introduction suggegts, my net will only capture members of the present OECD club with European origin (plus Argentina and Brazil). ${ }^{1}$ All of us know that much of the convergence since 1870 disappears when the net is widened to include Eastern Europe (DeLong 1988) and if it were widened still further to include the Third World convergence would totally evaporate. Why the small net? Because I think the sources of convergence in the OECD club are themselves misunderstood, and it matters to get the facts right.

Figure 1 documents real wage convergence from mid-century to Great War. While the convergence was not as fast as that of the late 20th century, it was pronounced, and about as fast as average convergence over the full 150 years since 1850. Figure 3 shows that the late 19 th century real wage convergence was replicated by gross domestic product (GDP) per worker-hour. However, real wage convergence was a lot faster than GDP per worker-hour, and the globalization arguments which follow offer some reasons why. Table 3 reports the $\lambda^{\prime} \cdot \mathrm{w}$ wich emerge when so-called unconditional convergence equations are applied to this historical epoch. They imply a peak rate of real wage convergence between 1870 and 1890 of 1.2 percent per annum, and about 1 percent per annum over the 1870-1913 period as a whole.

1 The full real wage 17-country sample is Australia, Argentina, Belgium, Brazil, Canada, Denmark, France, Germany, Great Britain, Ireland, Italy, the Netherlands, Norway, Portugal, Spain, Sweden and the United States. The full GDP per worker-hour 15-country sample subtracte Argentina, Brazil, Ireland, Portugal and Spain, but adds Austria, Finland and Switzerland. Thus, Maddison's sample has no Latin observations, either old World or New, and does not treat separately one of the best examples of catching-up, Ireland. 
While impressive, the late 19th century rate of convergence implies that real wage gaps would still have persisted well into the present century even had the convergence not been interrupted: for example, wage gaps in 1940 would still have been half of those 1870 big gaps. Big initial gaps take a long time to erase, even when convergence is persistent. But it was not persistent: an anti-convergence regime intervened which stopped convergence between 1914 and 1950. Figure 2 documents the interruption. The Great War produced real wage divergence, both the $1920 \mathrm{~s}$ and the $1930 \mathrm{~s}$ produced stabilty in real wage dispersion, and World War II produced more divergence. Figure 4 tells a similar, but less dramatic, tale: GDP per worker-hour convergence slowed down sharply between 1913 and 1938. Once again, real wage dispersion exhibits more dramatic behavior than GDP per worker-hour, and the rest of this paper will offer some explanations for the difference.

There are instructive country performances hidden by these summary statistics, especially the big North American outliers, Canada and the United States, both of whom buck the convergence tide. Ag Gavin Wright (1990), Moses Abramovitz and Paul David (1995) have argued, North America enfoyed a spectacular leap into industrial superiority after the early 1890s. The great leap forward is manifested by the rich North American New World improving its advantage over the poorer industrial old World after 1890: real wages in the United States were 72 percent higher than in Britain in 1870; that wage advantage had diminished to 63 percent by 1890, supporting convergence; but by 1913 the United States regained everything it had lost. Canada offers an even better example of North American resistence to convergence. Canada improved its real wage superiority from 48 percent above Britain in 1870 to 57 percent in 1900 and, riding the prairie wheat boom, to 123 percent in 1913.

This deviant North American behavior tended to retard the rate of convergence in the late 19th century, and Figures 1 and 3 show jugt how much. The "full sample lesg North America" converges faster than the full sample itself. Indeed, while the former traces out an abrupt switch from real wage convergence to divergence around the turn of the century, the latter continues 
the post-1850 convergence at about the same rate (Figure 1). The GDP per worker-hour evidence suggests the same (Figure 3).

Some might argue that this deviant behavior would be even more pronounced if the industrial North was treated separately. Maybe yes, maybe no. After all, regional inequality was not simply an American problem since it applied with equal drama to European countries like Italy. While I will stick to national definitions in what follows, I am aware of regional experience with convergence and divergence (Williamson 1965), and of an older literature which distinguished between regional "backwash" (Myrdal 1957), "polarization" (Hirschman 1958) and "spread" effects. There is reason to believe that the globalization and convergence forces which operated at the national level also operated at the regional level (Barro and Sala-i-Matin 1991), but I do not have the space here to pursue the issue in depth.

What about Europe? Given the great debate about Britain's loss of industrial leadership to her close competitors, most of us would look for evidence of, say, German catch-up on the leader. We would be looking in the wrong place. What matters far more to European convergence is the performance of poor countries around the European periphery. Over the thirty years following 1870, four of these poor countries dramatically improved their real wages relative to Britain: Denmark rose from 54 to 85 percent; Ireland, from 73 to 89 percent; Sweden, from 42 to 82 percent; and Norway, from 42 to 65 percent. Italy also made gains, but they were more modest. The Iberians lost ground: Portugal fell from 48 to 42 percent of Britain, and spain from 76 to 48 percent.

If convergence was relatively slow in Europe in the late 19th century, it was the rise in the historically persistent wage gap between the Latin South and the non-Latin North which accounts for it, and this in spite of so much attention to an alleged late Victorian and Edwardian failure in England. Late Victorian and Edwardian failure helps explain continued convergence in the North of Europe, but what dominated European experience was not Britain's failure (which hastened convergence), but the failure of the Latin economies 
(which retarded convergence). Figure 1 shows this clearly: real wage convergence in the OECD club is considerably greater when the two Iberian countries are removed from the sample.

Three countries illustrate the convergence best, Ireland, Sweden, and the USA. In 1854, real wages in Sweden were only 48 percent of Britain, while in 1913 they were at par, an impressive catch-up by any standard. In 1854, and shortly after the famine, real wages in Ireland were only 60 percent of Britain, a figure that had hardly changed at all over the previous three decades. Real wages in Ireland started a dramatic convergence on those across the Irish Sea during the 1850s (and, notably, in the absence of any Irish industrialization) so that they were 73 percent of Britain by 1870 . By 1913 they were 92 percent of Britain. Ireland was transformed over this period of convergence from a poverty-stricken, peasant economy which had served as a source of elastic labor supply for Britain's booming cities, to an economy at the start of the 20th century which boasted urban wages close to those prevailing in English cities. Irish and Swedish wages even converged on the New World between 1854 and 1913: as a percent of United States wages, Irish wages rose from 38 to 53 and Swedish wages rose from 24 to $53 .^{2}$ Now, why do I think globalization accounts for most of this convergence?

\section{Globalization in Commodity Markets:}

The Factor-Price Convergence Theorem at Work

The factor-price-equalization theorem has been a durable tool for trade theorists ever since Eli Heckscher and Bertil Ohlin made their seminal contributions in 1919 and 1924 (Flam and Flanders 1991), although it was

2 As it turns out, the average wage gap between New World and old drives a large share of the convergence over the half century from 1854 to 1913 (Williamson 1995). 
convergence not equalization that held the interests of these two Swedes. ${ }^{3}$ The Heckscher-ohlin paradigm argues that countries export commodities which use intensively the factors in which they are well endowed while they import commodities which use intensively the factors in which they are poorly endowed. Let falling transport costs tend to equalize prices of the traded commodities, encouraging more trade. Countries will now export more of the goods which exploit their favorable factor endowment. The demand for the abundant and cheap factor booms while that for the scarce and expensive factor falla. Thus, commodity price convergence tends to produce factor price convergence: for example, wages should rise in poor countries relative to rich. It follows that trade can be a substitute for labor and capital mobility in generating wage or labor productivity convergence.

Heckscher and ohlin were writing just after the spectacular late 19th century Scandinavian catch-up, and they were motivated by the commodity price convergence which they thought had taken place in the Atlantic economy. Their economic metaphor was driven by primary foodstuffs: the New World grain invasion, carried by the sharp decline in transport costs, served to lower the relative price of grains in Europe, and to raise it in North America.

Liverpool was the major port handling Britain's grain trade while Chicago was the city closest to America's grain producers, so it is the Liverpool-Chicago price gap that mattered most. Liverpool prices exceeded Chicago prices by about 60 percent in the three years centered on 1870 while they exceeded Chicago prices by lesg than 15 percent in the three years centered on 1912 . The price convergence was also manifested by beef, pork, bacon, mutton, butter, bar iron, cotton textiles, coal, copper, hides, wool, tin, cotton and many other tradables (O'Rourke and Williamson 1994, Table 2, Panel B). Had there been no other force at work, the terms of trade between manufactures and foodstuffs would have changed dramatically in both countries.

3 This section drawg heavily on a recent collaboration with Kevin 0 'Rourke on late 19 th century Scandinavian catch-up (O'Rourke and Williamson 1995) as well as earlier joint work on Anglo-America (O'Rourke and Williamson 1994 ). 
If Britain had absorbed all of the transport-induced price shock, her terms of trade would have almost doubled. If America had absorbed all of the transportinduced price shock, her terms of trade would have more than doubled. These were very big price shocks, exactly the kind which are supposed to set factorprice convergence in motion, and a computable general equilibrium (CGE) model is precisely the tool to use to assess that alleged impact.

CGE models are certainly not new to economists since they are common in development, trade and public finance (Shoven and whalley 1992). Nor are they new to economic history (James 1984; Thomas 1987). Indeed, I suppose I must take some responsibility for their use in economic history: I started applying them to historical problems in the early $1970 \mathrm{~s}^{4}$ after exploring their use on Third World development questions with Alan Kelley (Kelley and williamson 1971; Kelley, Williamson and Cheetham 1972; Kelley and Williamson 1973, 1974). They are perfect for this trade-convergence problem, as Peter Passell, Gavin Wright, Clayne Pope and John James suggested in the 1970s when assessing the ante bellum debates on tariff and land policy (Passell and Schmundt 1971; Passell and Wright 1972; Pope 1972; James 1978) or even earlier in the 1960s when Peter Temin and Robert Fogel collided on the American labor scarcity debate (Temin 1966; Fogel 1967). Kevin O'Rourke and I (1994) have used them in the 1990s to show that commodity price convergence had a significant impact on Anglo-American factor price convergence. Commodity price convergence explains more than a third of the decline in the Anglo-American real wage gap over the quarter century ending in 1895. Because of powerful offsetting forces, AngloAmerican convergence stopped after the early 1890s even though the factorprice-convergence effect of commodity trade persisted. Commodity price convergence played a significant role in fostering real wage convergence up to 1895 -- just as Heckscher and Ohlin predicted -- and in muting the powerful divergence forces set in motion by a much-debated industrial "failure" in Britain and by industrial success in North America based on a large market

4 Guided by the influence of Ron Jones, with whom I jointly ran a summer workshop in 1972 at the University of Wisconsin. 
size and a rich mineral resource base (Chandler 1977; Wright 1990; Abramovitz and David 1995).

What about Sweden, the classic European catch-up case that motivated Heckscher and ohlin in the first place? How much of the impressive AngloSwedish and American-Swedish convergence can be explained by commodity price convergence, trade creation and those Heckscher-Ohlin forces? To the extent that sweden retreated behind tariff walls in the 1880s, perhaps the price convergence set in motion by the global collapse in international transport costs was muted or even offset. Kevin O'Rourke and I (1995) have recently shown that there was price convergence between Sweden and Britain over the late 19th century, as the former integrated into the global commodity market with the latter at its center.

It turns out, however, that Anglo-Swedish price convergence was modest, suggesting that the Heckscher-ohlin factor price convergence effects must also have been modest. Once again we use a CGE model to assess those effects, exactly the kind of model first proposed by Bertil ohlin and now so commonly used in trade theory. The CGE model estimates that the price convergence with Britain served to raise urban wages in Sweden by only 2 percent above what would have been true in its absence and thus it explains only 4 percent of the impressive erosion in the Anglo-Swedish wage gap. Adding the large AngloAmerican Heckscher-ohlin effect to the small Anglo-swedish effect yields an American-Swedish figure of perhaps a tenth.

So far, Heckscher and ohlin get mixed reviews: commodity price convergence accounts for about three-tenths of real wage convergence between the United states and Britain during the twenty-five years after 1870, and about a tenth of the convergence between the United states and sweden over the four decades after 1870; however, Anglo-American commodity price convergence effects were swamped by other forces after 1895, and they made only a modest contribution to Anglo-Swedish real wage convergence over the four decades as a whole. Kevin O'Rourke, Alan Taylor and I (1995) turned to econometric analysis of wage-rental trends in seven countries (including Britain and sweden) to 
search for the modal case. The study found that commodity price convergence could explain about a quarter of wage-rental convergence between the New World and the old World (O'Rourke, Taylor and Williamson, 1995, Table 4 ).

Trade was a substitute for factor flows in the late 19th century, but it was hardly a perfect substitute. Imperfect substitute or not, there are three corollaries suggested by this historical theorem. First, countries which raised high barriers to trade were less likely to be part of the convergence (like spain and Portugal). Second, de-globalization and the move to autarchy between 1914 and 1950 must have contributed to the observed cessation in convergence. Third, the gradual reconstruction of world commodity markets since 1950 must have contributed to the resumption of convergence.

So say the lessons of history regarding globalization in commodity markets. What about factor markets, and mass migrations in particular?

\section{Globalization in Labor Markets: Mass Migration and Convergence}

In its 1911 Report, the US Immigration Commission concluded that mass immigration injured American labor -- unskilled immigrants displaced both natives and older immigrant cohorts and undercut their living standards. 5 The literature which followed largely discredited the Report for its racial overtones, its selective collection of data, and its sloppy analysis, but the Commission's big question lingers on: Did immigrants crowd out residents and lower their living standards? If the answer to this first question is yes, then did us immigration by itself contribute substantially to global convergence? If the answer to this second question is also yes, then what contribution did mass migration make to raising living standards in the poorer parts of Europe relative to the richer parts of Europe and to the richer New World?

5 The first half of this section, dealing with the United Stateg, draws heavily on a book collaboration with Timothy Hatton, Understanding Mass Miqration in the past (1995b: Chapter 8) and a joint paper (Hatton and Williamson, 1995a). 
True, analysts then and now have focused their attention on the Commission's views on assimilation. Yet the real obsession of that time was instead the macro impact of the immigrants on American employment conditions, living standards and wages. According to the Commission, real wages would have increased much more had immigrant labor supplies from southern and eastern Europe been absent (1911, vol.8: 440). Hourwich rejected this kind of counterfactual thinking, preferring instead to emphasize that substantial gains in real wages had in fact taken place after the 1880s, thus concluding that immigration could not have retarded wage growth (1922: 295-307). More careful authorities, however, concluded just the opposite: Paul Douglas (1930: 564) and Stanley Lebergott (1964: 163) compared real wage growth in the period from the $1890 s$ to 1914 with that in the 1920 s thus concluding that mass immigration slowed real wage growth in the pre-quota period. Apart from studies like these, historians had, until only very recently, ignored the question of macro impact.

Meanwhile, contemporary economists have generated a sizeable literature dealing with the impact of late 20th century immigration and most of them have found the effects to have been tiny (Greenwood and McDowell 1986, 1994; Simon 1989: Borjas 1990, 1994). These studies tend to look across local labor markets for their evidence. As such, they almost certainly understate (or miss entirely) the economy-wide impact of immigration on wages. After all, foreign in-migration will only lower wages in a local labor market if it increases the total labor supply. If instead there is completely offsetting native outmigration, then a rige in the immigrant share is consistent with no change in the rize of the local labor force, and no immigrant-induced wage effect compared with other local labor markets in which natives relocate. But wages should fall (perhaps equally, perhaps not) in all locations. These macro effects are not measured by the local labor market studies.

Perhaps a better way to isolate the impact of immigration is to estimate the wage adjustment mechanism from time series. Timothy Hatton and I (1995a, Table 6; 1995b, Chp. 8) recently did so on annual us observations for 1890- 
1913. The econometric results were excellent, and their implication was that the 1913 real wage would have been 5 or 6 percent higher in the absence of net immigration.

Local labor market and time series estimates may both fail to capture the full impact of immigration on national wages. They make no allowance for output shifts between sectors, events with macro factor-demand implications which are likely to have taken place in response to immigration. That is, they ignore the fact that international trade and domestic demand might have helped accomodate the immigrant influx by more job creation due to supply-side stimulus in labor-intensive sectors and to demand-side stimulus in investment in housing and social overhead. Nor do they allow capital to chase labor across the Atlantic, offsetting the decline in the capital-labor ratio which American immigration would otherwise have induced. These real world complications are likely to have made it easier for America to absorb the immigrants without big living standard losses for natives. The best way to accomodate such complications is to evaluate the effects of international migration with a computable general equilibrium model.

CGEs have certainly been used before to analyze both contemporary and historical migration problems (Hamilton and Whalley 1984; Williamson 1974; Williamson 1990: Boyer, Hatton and O'Rourke 1994; O'Rourke, Williamson and Hatton 1994; O'Rourke and Williamson 1995). The first effort to apply a cGE to late 19 th century United states estimated that Immigration after 1870 lowered real wages by 11 percent in 1910 (Williamson 1974: 387), a period twice as long as the time series just cited which yielded 5-6 percent. ${ }^{6}$ Doubling our time series estimate to make it comparable with the longer period suggests something like 10-12 percent, almost identical to my earlier finding of 11 percent. Claudia Goldin's (1994) recent cross-section estimate for the period between 1890 and 1915 is almost exactly the same.

Another CGE experiment was implemented by Timothy Hatton, Kevin O'Rourke

6 My 11 percent 1974 estimate for 1870-1910 was also confirmed a little later by Peter Lindert and myself (1980). 
and myself (0'Rourke, Williamson and Hatton 1994). By deducting those estimated to have arrived before 1870, and by applying age/sex specific participation rates to the remainder, the direct contribution of immigration to the labor force was derived for 1890 and 1910 . The calculation also accomodated the labor force impact of the children of immigrants (based on the fertility of foreign-born females). Our calculations suggest that the us labor force would have been 13 percent smaller in 1890 without the net immigration from 1870 to 1890 , and about 27 percent smaller in 1910 without the net immigration from 1870 to 1910. Alternatively, immigration after 1870 served to augment the Us labor force by 15 percent in 1890 and 37 percent in 1910. While these measured impacts are big, they would be a lot bigger if one believed that southern labor markets were completely segmented from the rest of the United States (Wright 1986): immigration served to augment labor supplies in the North by more than in the country ag a whole. Since I ignore this possibility in what follows, I understate the impact of immigration on real wages in urban labor markets in America.

The impact of immigration is estimated under two alternative assumptions about international capital markets. The first treats the Us as completely closed to world capital markets and assumes that the domestic capital stock is unaffected by the more slowly growing labor force in the 'no immigration' counterfactual. While a very bad assumption, it is commonly made even in debates about the impact of late $20 \mathrm{th}$ century immigration on American or European labor markets. The effects are very big under that dubious assumption. In the absence of immigration after 1870 , the urban real wage would have been 14 percent higher in 1890 and 34 percent higher in 1910. If the Immigration Commission had any intuition about an impact of that size, it certainly would have had every cause to produce a 1911 Report which supported immigrant quotas!

But in this imaginary world of no foreign capital flows, rates of return to capital must have been higher with more (immigrant) labor than with less. So, what happens when foreign capital from Britain and elsewhere in Europe is 
allowed to chase after the emigrants going to the United States? Suppose one assumes that the global capital market was perfectly integrated and that the United States faced an elastic supply of world capital. Under these assumptions, less capital would have migrated across the Atlantic and in the 'no immigration' counterfactual the marginal product of capital would have remained constant. While the rise in the marginal product of labor would therefore have been attenuated, it would not have disappeared since 1and-labor ratios would still have been higher under the capital mobility assumption. Bottom line? In a world without immigration after 1870 , but with elastic world capital flow responses, the real wage in the United States would have risen additionally by almost 4 percent by 1890 and more than 9 percent by 1910 . Meanwhile, what was the impact of emigration on European labor marketa? As with American immigration, European emigration generated no shortage of political debate. Some feared that the emigrations drained the home country of the best and the brightest. Post-famine Irish commentators viewed the emigrant flood as evidence of Ireland's failure to industrialize and thus its inability to create enough good jobs. ${ }^{8}$ Some saw the flood in even more negative terms, as one more cause of industrial failure since they thought the best was being creamed off the top of the labor force. Some even argued that Ireland failed to industrialize because its home market for industrial goods was too small; once too small, scale economies were hard to achieve, Irish manufacturing lost its competitive edge and industrial job creation faltered; emigrants fled the stagnant Irish labor market; and the market got even smaller. Such commentary would imply that a dismal path-dependent historical process was at work which insured Irish industrial failure (ó Gráda 1994: 342-7).

7 Zevin (1992) and obstfeld (1994) have both shown that world capital markets were at least as well integrated in the 18908 as in the 1980s, perhaps even better.

8 ó Gráda (1994: Chp. 13). The remainder of this section draws on Understanding Mass Migration in the Past (Chapters 9 and 10) with Timothy Hatton, his research with other collaboratorg on Ireland (Boyer, Hatton and O'Rourke, 1994), a paper on Sweden by Kevin O'Rourke and myself (O'Rourke and Williamson 1995) and a "global" paper by Alan Taylor and myself (Taylor and Williamson, 1994). 
On the other hand, Ireland did undergo an impressive catch-up on both Britain and America after the famine (williamson 1994). Economics as old as Adam Smith can explain why: emigration made labor more scarce in Ireland, thus raising real wages and living standards at home even compared with conditions overseas where immigration made labor more abundant. This kind of Smithian economics exploits diminishing returns: given land, capital, technology and resources, more labor means lower real wages and living standards; less labor means higher real wages and living standards. While the movers may have been able to escape to higher wages abroad, the now-scarcer stayers found conditions improving at home.

Swedish commentators also viewed emigration as a sign of failure: surely, they seemed to be saying, it is a poor economy that cannot generate enough good jobs to keep our young swedes at home. The Swedes left in especially large numbers in the 1880s, and the debate became most intense right about that time. And this despite the fact that sweden in particular, and Scandinavia in general, was in the midst of the most impressive European catch-up by far, and a catch-up which, in contrast with Ireland, seemed to be carried by vigorous industrialization (O'Rourke and Williamson 1995). Knut Wicksell wrote a popular essay in 1882 which argued the Smithian case: emigration would eventually solve the pauper problem which blighted laborabundant and land-scarce Swedish agriculture and thus was a good thing to be tolerated, perhaps even stimulated (cited in Karlstrom 1985: 155).

What was the impact of mass emigration on the sending country? The literature is loud on assertion but quiet on evidence, even though more than a century has passed since Wicksell's essay on sweden appeared and a century and a half since the post-Famine emigrant flood spilled out of Ireland. Using CGEs that allow for elastic world capital supplies, George Boyer, Timothy Hatton and Kevin O'Rourke (1994) were able to show that post-famine Irish emigration accounted for an enormous third to a half of the rise in real wages at home and for a third of income per head. It follows that Irish emigration accounted for at least 60 percent of the convergence between Ireland and both Britain 
and the United States. While we have yet to add up the impact of mass migration on both sending and receiving labor markets, Irish emigration by itself made a powerful contribution to Irish real wage and living standard convergence on Britain and the United States. The Swedish story is less spectacular but still impressive. Kevin O'Rourke and I (1995) have shown that Swedish emigration between 1870 and 1910 served to raise Swedish wages by about 12 percent above what they would have been in its absence.

European emigration had a significant impact on labor markets at home: the departure of the movers improved economic conditions of the stayers faster than would have been true without emigration -- raising real wages, lowering unemployment and eroding poverty by more. By glutting labor markets abroad, the mass migrations also reduced the pace of real wage growth in receiving countries. Thus, mass migration tended to create economic convergence among the participating countries -- living standards in the poor emigrating countries tended to catch up with living standards in rich immigrating countries. Not all countries participated, some had offsetting influences, and some had more induced catch-up than others, but the underlying tendencies must have been pervasive.

Exactly how pervasive? To answer this question, Alan Taylor and I (1994) asked another: what would have been the measured convergence 1870-1910 had there been no mass migration? The no-migration counterfactual invokes the ceteris paribus assumption: in each country, we adjust population and labor force according to the average net migration (and labor participation) rate observed during the period, and assume that technology, capital stocks, prices and all else remain constant. This time the analysis was partial equilibrium and it was implemented by the econometric estimation of labor demand in sending and receiving countries. ${ }^{9}$ Using the estimated labor demand functions, what was the impact of mass migration on convergence? Once again, the answer

9 Labor demand equations were estimated by using panel fixed-effect techniques on a 14-country sample over the four decades 1870-1910 (Taylor and Williamson, 1994, Appendix 2). The results were very close to modern estimates (Hammermesh 1993). 
depended on what one assumes about world capital markets. In the absence of the mass migrations, wages and labor productivity would have been a lot higher in the New World and a lot lower in the old; and in the absence of the mass migrations, income per capita would normally have been somewhat higher in the New World and somewhat lower in the old World. The impact was biggest, of course, when domestic capital stocks were nowhere allowed to respond to the mass migrations. A silly assumption, but at least it establishes an upper bound. We will start there.

Not surprisingly, the biggest counterfactual impact was for those countries which experienced the biggest migrations: by 1910, Irish wages would have been lower by 36 percent, Italian by 33 percent and Swedish by 12 percent; and Argentine wages would have been higher by 46 percent, Australian by 28 percent, Canadian by 31 percent and American by 15 percent. Still ignoring global capital market responges, the analysis suggests that in the absence of the mass migrationg real wage dispersion would have increased by 42 percent between 1870 and 1910, when in fact it decreased by 28 percent. GDP per worker dispersion would have decreased by only 9 percent rather than by the 29 percent observed. GDP per capita dispersion would also have decreased by only 9 percent rather than by the 18 percent observed. Wage gaps between New World and old actually declined from 96 to 79 percent between 1870 and 1910, but in the absence of the mass migrations they would have risen to 150 percent!

Pairwise comparisons are also easily constructed. Wage gaps between many old World countries and the US fell dramatically as a result of mass migration: without Irish emigration (some of whom went to America) and US immigration (some of whom were Irish), the American-Irish wage gap would have risen by 101 percentage points, while in fact it fell by 48; without Italian emigration (a large share of whom went to America) and US immigration (many of whom were Italian), the American-Italian wage gap would have risen by 149 percentage points, while in fact it fell by 102 ; without British emigration and Australian immigration, the Australian-British wage gap would have fallen 
only by 4 percentage points, while in fact it fell by 55; and without Italian emigration and Argentine immigration, the Argentine-Italian wage gap would have risen by 187 percentage points, while in fact it fell by 45 . Furthermore, the mass migrations to the New World had an impact on economic convergence within the old World: without the Norwegian emigration flood and the German emigration trickle, the German-Norwegian wage gap would have fallen by 67 percentage points, while in fact it fell by 83; and without the fact that Irish emigration exceeded British emigration by far, the British-Irish wage gap would have risen by 25 percentage points, while in fact it fell by 26 .

These counterfactuals suggest that all of the real wage convergence between 1870 and 1910, almost three-quarters of the GDP per worker convergence, and perhaps one half of the GDP per capita convergence was due to mass migration. The relative insensitivity of GDP per capita convergence to migration can be explained easily enough. High migrant labor participation rates amplify the impact of population migration on real wages or GDP per worker, but the impact on GDP per capita is muted. Why? Migration has a big impact on the labor force, GDP per worker and wages, since the labor content of the migrations is big. Migration has a smaller impact on GDP per capita for much the same reasons: emigration may raise GDP per worker by offseting diminishing returns in production -- a positive impact on GDP per capita, but selectivity assures that emigration will take away a disproportionate share of the labor force -- a negative impact on output per capita. The latter effect was strong in the late 19th century Atlantic economy, so muted effects of mass migration on GDP per capita convergence are no surprise.

Now let's purge that silly assumption about no world capital market responses, and assume instead that there would have been a foreign capital flow response in the no-migration counterfactual. That is, migration augments the labor force in the rich country relative to the poor, lowering capitallabor ratios in the rich country relative to the poor, raising capital's productivity in the rich country relative to the poor, and thus encouraging the flow of capital from poor country to rich. In short, capital chases after 
labor. Indeed, what happens in the no-migration counterfactual when the labor supply shocks generate a large enough capital inflow or outflow to maintain a constant rate of return on capital in each country? It turns out that the capital-chasing-labor offsets are very large. ${ }^{10}$ But the net result with capital chasing is that mass migration still accounts for 70 percent of the real wage convergence between 1870 and 1910, leaving approximately 30 percent to other forces, like the trade forces stressed by Heckscher and ohlin. Mass migration and trade explain an enormous share of the convergence observed in the late 19 th century. It follows that migration and trade restrictions associated with war and policy must go a long way in explaining why convergence stops after 1914. While this lesson of history gounds plausible, nobody has yet constructed an explicit test. Furthermore, what happened to the other, more traditional, closed-economy explanations for late 19 th century convergence?

\section{Schooling and 19th Century Convergence}

When economists estimate what is known as the conditional convergence equation on late 20 th century evidence, they almost always include schooling. 11 When they do, schooling matters, especially in predicting which countries are members of the convergence club and which are not. Does it follow that schooling also played a powerful role in the late 19 th century? Maybe yes, maybe no. After all, technologies were much less skill-intensive in

10 The big late 19 th century capital flows went from old World to New World rather than from center to periphery within the old World. That ia, it chased after labor migrating to (rich) surplus natural resource areas. Thus, the majority of the late 19 th century international capital flows did not contribute to convergence. This is consistent with Barro, Mankiw and Sala-iMartin (1995) who find the quantitative impact of global capital flows on late $20 t h$ century convergence "small". However, the Nordic fringe offers a spectacular late 19 th century exception: a very large share of their dramatic catch-up on the leaders was accounted for by capital flows (O'Rourke and Williamson, 1995).

11 For example, Mankiw et al. (1992, p. 426) or Barro (1991). 
the 1890 s than they are today. ${ }^{12}$

My view is that schooling was a minor player in late 19th century convergence. I suspect it became a major player only in the late 20th century. Economic historians don't seem to share my view. In 1979, Lars Sandberg published "The Case of the Impoverished Sophisticate" which explored the relationship between schooling and Swedish economic growth before World War I. Sandberg did not offer an explicit test of his schooling hypothesis at that time, but no one has stated the proposition with greater clarity, including the new growth theorists or Richard Easterlin in his 1981 Presidential Address to this Association. Carlo cipolla (1969, Table 6, p. 72) certainly offered plenty of evidence in support of the impoverished sophisticate view and, based on such evidence, argued that the "more literate countries were the first to import the Industrial Revolution" (p. 87). By 1850, Sweden was the most literate country in Europe and was the only European country that could measure up to the United States in that dimension (Sandberg, 1979, p. 230). Indeed, in a later paper Sandberg used Cipolla's qualitative literacy data to show that the 1850 educational ranking was highly correlated with the 1970 per capita income ranking, and that up to 1913 "the poor, high literacy countrieg ... grew the fastest ... [while] the low literacy countries ... [grew] slower" (Sandberg, 1982, p. 689). Gabriel Tortella (1994) has recently elaborated on this theme while searching for explanations of economic backwardness in the Mediterranean basin.

While these studies certainly find correlations in the data, they do not assess the contribution of schooling to convergence. ${ }^{13}$ Kevin $O$ 'Rourke and I (1995, 1996) recently filled this void by estimating standard convergence

12 Schooling may also play a more modest role simply because our convergence sample excludes very poor countries in Eastern Europe, much of the Mediterranean, Asia and the rest of what now is called the Third World.

13 As far as I am aware, only Leandro Prados and his collaborators (Prados, Sanchez and Oliva 1993) have attempted to estimate pre-World War II convergence equations conditional on schooling. However, they do not estimate the impact of schooling by epoch, nor do they tell us whether the contribution of schooling to convergence has varied since the mid-19th century. 
equations on late 19th century data conditioned by schooling, where the latter was proxied first by enrollment rates (the standard proxy) and second by literacy rates. The conditional convergence equations were estimated on both real wage data (Williamson 1995) and GDP per worker data (Maddison 1991). The underlying data base has been revised since, but Panel A in Table 4 suggests that our earlier results are robust. The contribution of schooling to GDP per worker growth is never statistically significant, supporting the view that schooling was far less important to late 19th than to late 20th century growth. However, the contribution of schooling to real wage growth is significant. ${ }^{14}$ As predicted by Abramovitz, Easterlin, Sandberg, Tortella and the new growth theorists, schooling levels "conditioned" real wage convergence in the late 19 th century. Poor countries well endowed with schooling caught up faster than those poorly endowed, presumably because their "social capabilities" were better established. That is, they were better able to exploit open economy and globalization effects. Furthermore, when conditioned by schooling, the rate of real wage convergence $(\lambda)$ rises from 1.2 to 1.7 or 1.8 percent per annum.

What we really want to know, however, is whether schooling played a central role in accounting for convergence. We can find out by asking another question: How much of each country's "deviant" growth performance between 1870 and 1913 was due to each country's "deviant" schooling performance? As the notes to Panel $B$ in Table 4 indicate, "deviant" growth is defined as the residual left over after controlling for initial real wage levels (a proxy, at least in part, for the impact of globalization), while "deviant" schooling is simply how much it exceeded the average. Panel B answers the question. First, in twelve of thirty-two cases, schooling didn't matter at all. These were

14 This result is surprising. After all, the real wage growth is for "raw" unskilled labor and only measures changing labor scarcity and labor productivity within one (un)skilled category. GDP per worker-hour growth aggregates the impact of changing labor productivity within skill categories and changing labor productivity due to country-wide shifts up the skill ladder. We have also experimented with the addition of changes in schooling, but the regults were poor. Table 4 and the text sticks, therefore, with levels of schooling on the right hand side, as does most of the empirical new growth literature. 
almost always European industrial leaders who, presumably, had already fulfilled some minimum schooling pre-condition. Where schooling mattered consistently was around the European periphery: good schooling accounted for from 14 to 57 percent of "deviant" good growth in Scandinavia (Denmark, Norway, Sweden); bad schooling accounted for from 11 percent to all of "deviant" bad growth in the Mediterranean basin (Italy, Portugal, spain). For the full sample, schooling accounted for about a third of "deviant" growth. It did not account for a third of growth. It did not account for a third of growth above or below average. It did not account for a third of convergence. Rather, it accounted for a third of the residual growth after controlling for initial 1870 conditions. We have already argued that those initial conditions explain most of the convergence in the late 19th century environment of globalization: poor countries sending out emigrants; rich countries absorbing immigrants; and trade between rich and poor countries inducing factor price convergence.

Schooling mattered to late 19 th century convergence, but: it mattered only to real wage growth and not to GDP per worker-hour growth; it mattered mostly to "fust" the European periphery; and it accounted for only a small share of total convergence.

\section{Minor Players in 19th Century Convergence:}

Induced Factor-Saving, Technological Transfer and Other Imponderables

What about technological convergence and the transfer of technologies? Alexander Gerschenkron (1952) thought the answer to convergence lay with the fact that backward countries had more to gain by eliminating the productivity gap between best modern practice in rich countries and primitive traditional practice in poor countries. Thus, poor countries had the highest growth potential. As Moses Abramovitz (1986) pointed out, a country's "social capability" will determine whether the poor country exploits that potential, where "social capability" can be proxied by schooling. 
There are at least four problems with this otherwise plausible explanation: First, industrial technologies were well known the world around in the late 19th century and schooling was not as important on the plant floor as it is now. There were few industrial mysteries to transfer, and schooling wasn't central to the process. Second, as we have seen empirically at the macro level, schooling wasn't all that important to the convergence process, at least amongst members of our OECD club. Third, poor European countries had little to learn from rich New World countries at least before the turn of the century. For example, Robert Allen has shown that American blast furnaces had no distinctive world-class stature worth copying prior to the 18908 (Allen 1977; see also wright 1990). To take another example, can anyone cite one example of Australian technology transfered to Europe in the late 19th century? And reminiscent of Simon Kuznets (1966) and Edward Denison (1967), Steve Broadberry (1995a, 1995b) has recently pointed out that it was industrialization that mattered most to catch-up in the late 19th century, not technological catch-up within industry. Need I point out that rapid industrialization in poor, labor-abundant countries was strongly conditioned by globalization forces? This, after all, offered the critical vent-forsurplus-industrial-output in those poor countries whose home markets were too small to absorb the new industrial output by themselves.

Finally, for agriculture at least, there is a long tradition documenting technological divergence, not convergence. H. J. Habakkuk (1962), Yujiro Hayami and Vernon Ruttan (1971), and Paul David (1975) have used the induced innovation hypothesis to accomodate the facts that: poor labor-abundant economies in the 19th century searched for and found labor-using and landsaving technologies; rich labor-scarce economies searched for and found landusing and labor-gaving technologies. The effect was to diminish the importance of what were otherwise wide differences in the relative endowments of land and labor: it served to raise labor scarcity in the poor old World and lower it in the rich New World.

But were these factor-saving forces important in accounting for 
convergence during the late 19th century? Apparently so: factor-saving productivity advance seems to have acccounted for almost half of the trends in the ratio of farm rents to wages (O'Rourke, Taylor and Williamson 1995). ${ }^{15}$ Whether these powerful forces were primarily limited to agriculture and farm rents, or whether they influenced more generally economy-wide real wage and labor productivity convergence has yet to be determined. Perhaps most of the land-saving was induced by the relative demise of agriculture in favor of industry: after all, industrialization tends to be land-saving, raising instead the relative demands for labor and capital. If so, then we may simply be putting new labels on forces already identified. Important factor-saving forces are consistent with Broadberry's focus on industrialization, and thus with globalization which, after all, was the "handmaiden" of industrialization. ${ }^{16}$

\section{Is Convergence a cood Thing? Who Gains and Who Loses?}

Here are two bromides. Bromide Number One: Big factor price differentials across countries imply poor global resource allocation and big Harberger triangles. Erosion of those factor price differentials implies better global resource allocation and higher global income (Hamilton and Whalley 1984). Bromide Number Two: Catch-up achieved by faster growth among poorer countries has much more positive welfare implications than catch-up by slower growth among richer countries.

While true, these two bromides are not very helpful in assessing whether convergence is a good thing. Convergence of what? The new growth theory has shown very little interest in who gains and who loses from convergence. The

15 Factor-saving mattered to late 19 th century convergence, and it appears that this effect is not some quaint historical aberration since it reappears in a somewhat different guise in the cross-sectional accounts of trade patterns in the 1980s (Trefler 1993).

16 I refer here to Irving Kravis's "Trade as a Handmaiden of Economic Growth" (1970). 
theory tends to be highly aggregative, and its empirical applications deal with coarse aggregates like gross domestic product per worker. What about wages of unskilled laborers, wages of skilled artisans, salaries of skilled clerical workers, farm rents accruing to landlords and profits accruing to capitalists? What about returns to sector-specific resources and capital? Understanding the sources of convergence is fundamental to understanding who gains and who loses from convergence, and thus to understanding policy responses. Consider three examples.

First: If the source of the convergence was some mysterious acceleration in factor-neutral productivity advance in poor countries, then it is much more likely that everyone gained from convergence. But productivity advance was not factor-neutral in the late 19th century. Rather, it saved on (unskilled) labor in rich countries while it saved on land in poor countries. Productivity convergence of this sort should have tended to raise wage-rental ratios in Europe and -- where land ownership was highly concentrated -- to move income distributions in a more egalitarian direction. The opposite should have been true of the New World, even though land ownership was not as highly concentrated. In Europe, unskilled labor gained and landowners lost by those factor-saving convergence forces. In the New World, unskilled labor lost and landowners gained from the convergence forces. Yet, it is hard to imagine any late 19 th century political response or policy action that would have altered these productivity events much.

Second: Suppose the source of convergence lay with the elimination of some market failure in institutionally-weak, rent-seeking and price-distorted poor countries. Suppose, for example, it took the form of state intervention to exploit the gap between social and private rates of return to schooling, or intervention to release liquidity constraints on the household's schooling decision. What then? Rising "social capabilities" should have accelerated catch-up in the poor countries. In addition, the newly-schooled escaping poverty in poor countries would have served to create more egalitarian income distributions. The poor who did not use schooling to escape poverty would at 
least have found themselves scarcer and able to command higher wages, thus implying even more egalitarian income distributions (Williamson 1991: chp. 2 and pp. 90-103). While such policies may have fostered catch-up and convergence, they clearly improved living standards of the working class. Furthermore, they should have improved the incomes of rich capitalists to the extent that capital and skills were complements, as we now believe. It follows that capitalists should have supported such policies. Since land and skills were less likely to have been complements (except in such cases as Danish agriculture), landed interests were less likely to have supported such policies.

Third: Suppose the source of convergence lay instead with the two open economy and globalization forces which we have stressed above, namely: international labor migration (in excess of the capital migration which often chased after the labor) and factor-price-convergence induced by global commodity market integration and trade booms. Here the distributional impact is even clearer and probably more powerful. Unskilled labor migration raised the relative price of unskilled labor in poor emigrating countries and lowered it in rich immigrating countries. These forces were reinforced by trade. Recall that powerful forces of global commodity market integration were at work in the late 19th century: the resulting trade booms shifted unskilled labor demand to the right in poor countries (compared with other factors) and to the left in rich countries (compared with other factors). These tradeinduced forces tended to have the same effect as the mass migrations: the relative price of unskilled labor tended to rise in poor countries and fall in rich countries. It follows that the skill premium, earnings inequality and income inequality should, ceterig paribus, have been falling in the poor European countries which were catching up. The faster the catch-up, the bigger the fall. In contrast, the skill premium, earnings inequality and income inequality should, ceteris paribus, have been rising in the rich New World countries. Since we believe the latter to have been true of America and the rest of the OECD since the 1970 s (Borjas, Freeman and Katz 1992; Lawrence and 
Slaughter 1993; Wood 1994; Burtless 1995; Krugman and Venables 1995), it should have been even more true of the late 19 th century when legal migration was so much bigger. The proposition needs to be strengthened with more evidence, but the prospects look good. After all, while British inequality started to decline following the late 1860 , the decline was delayed for about sixty years in the United States (Williamson and Lindert 1980; Williamson 1985; Lindert and Williamson 1985) and immigration, at least, must have made a contribution to the delay (Williamson and Lindert 1980; Williamson 1982).

\section{Does Convergence seed Its Own Destruction?}

Do pro-globalization policies persist, thus accommodating convergence, or do anti-globalization policies emerge, thus choking it off?

Globalization and convergence had a predictable influence on income and wealth: some gained and some lost. One would have expected increasingly loud political complaints from the losers. One would have expected emerging political alliances and stronger lobbying favoring policies to protect the losers. If the losers were able to persuade the rest that de-globalization was the only "fair" way to ease their economic damage, tariffg would have rigen and migration restrictions would have been imposed. Can the timing and magnitude of immigration restrictions after the $1890 \mathrm{~s}$ in the United States, more manipulative immigration policies in Canada, changing immigrant subsidies in Australia and Brazil, the alliance between iron and rye in Germany, and rising protection elsewhere on the continent be explained, at least in part, by the forces of convergence that had been taking place since the mid-19th century? Can the autarchic de-globalization from World War I to 1950 be explained, at least in part, by the same political economy dynamic?

As economic stress mounts in the 1990s, we need to understand far better the regime switch from globalization and convergence up to World war I to deglobalization and divergence up to 1950. Was the regime switch a product of the convergence itgelf? Can we expect the same over the next quarter century? 


\section{References}

Abramovitz, M. (1986), "Catching Up, Forging Ahead, and Falling Behind," Journal of Economic History $46: 385-406$.

Abramovitz, M. and P. A. David (1995), "Convergence and Deferred Catch-Up: Productivity Leadership and the Waning of American Exceptionalism," in R. Landau, T. Taylor and G. Wright (eds.), Growth and Development: The Economics of the 21st Century (Stanford, Cal.: Stanford Univergity Press).

Allen, R. (1977), "The Peculiar Productivity History of American Blast Furnaces, 1840-1913," Journal of Economic History 37: 605-33.

Barro, R.J. (1991), "Economic Growth in a Cross Section of Countries," Quarterly Journal of Economicg 106: 407-43.

Barro, R.J. and X. Sala-I-Martin (1991), "Convergence across States and Regions," Brookinas Papers on Economic Activity 1: 107-82.

Borjas, G. (1990), Friends or Strangers? The Impact of Immigrants on the U.S. Economy (New York: Basic Books).

--- (1994), "The Economics of Immigration," Journal of Economic Literature 32: 1667-717.

Borjas, G. J., R. B. Freeman and L. F. Katz (1992), "On the Labor Market Impacts of Immigration and Trade," in G. J. Borjas and R. B. Freeman (eds.), Immigration and the Work Force: Economic Consequences for the United States and Source Areas, (Chicago: University of Chicago Press).

Boyer, G. R., T. J. Hatton, and K. H. O'Rourke (1994), "Emigration and Economic Growth in Ireland, 1850-1914," in T. J. Hatton and J. G. Williamson (edg.) Migration and the International Labor Market, 1850-1939 (London: Routledge).

Broadberry, S. N. (1995a), "Convergence: What the Historical Record Showg," in B. van Ark and N. F. R. Crafts (eds.), Quantitative Aspects of Postwar European Growth (Cambridge: Cambridge University Press, forthcoming). (1995b), "Micro-Historical Foundations of the Convergence Debate," paper presented at the EHES Summer School, Groningen, The Netherlands (June 
$18-25)$.

Burtless, G. (1995), "International Trade and the Rise in Earninge

Inequality", Journal of Economic Literature 33: 800-16.

Cipolla, C. M. (1969), Literacy and Development in the West (London: Penguin). David, P. A. (1975), Technical Choice, Innovation and Economic Growth

(Cambridge: Cambridge University Press).

Denison, E. F. (1967), Why Growth Rateg Differ: Postwar Experience in Nine

Western Countries (Washinton, D. C.: Brookings).

de Long, J. B. (1988), "Productivity Growth, Convergence and Welfare:

Comment," American Economic Review 78: 1138-54.

Douglas, P. A. (1930), Real Wages in the United Stateg, 1890-1926, reprinted

1966 (New York: Augustus M. Kelley).

Flam, H., and M. J. Flanders (1991), Heckscher-Ohlin Trade Theory (Cambridge, Mass.: MIT Press).

Fogel, R. W. (1967), "The Specification Problem in Economic History," Journal of Economic History 27: 283-308.

Gerschenkron, A. [1952], "Economic Backwardness in Historical Perspective," in B. F. Hoselitz (ed.), The Progress of Underdeveloped Areas (Chicago: Univergity of Chicago Press).

Goldin, c. (1994), "The Political Economy of Immigration Restriction in the United States, 1890 to 1921," in C. Goldin and G. D. Libecap (eds.), The Regulated Economy: A Historical Approach to Political Economy (Chicago, University of Chicago Press).

Greenwood, M.J. and J. M. McDowell (1986), "The Factor Market Consequences of U.S. Immigration," Journal of Economic Literature 24: 1738-72.

--- (1994), "National Labor Market Consequences of U.S. Immigration," in H. Giersch (ed.), Economic Aspects of International Migration (Berlin: springer-Verlag).

Habakkuk, H. J. (1962), American and British Technology in the Nineteenth Century (Cambridge: Cambridge University Press).

Hammermesh, D. S. (1993), Labor Demand (Princeton, N.J.: Princeton University Press). 
Hamilton, B. and J. Whalley (1984), "Efficiency and Distributional Implications of Global Restrictions on Labor Mobility," Journal of Development Economics 14: 61-75.

Hatton, T. J. and J. G. Williamson (1995a), "The Impact of Immigration on American Labor Markets Prior to the Quotas," NBER Working Paper No. 5185, National Bureau of Economic Research, Cambridge, Mass. (July). --- (1995b), Understanding Mass Migration in the Past (ongoing).

Hayami, Y. and V. W. Ruttan (1971), Agricultural Development: An International Perspective (Baltimore, Md.: The Johns Hopkins Press).

Hirschman, A. O. (1958), The Strategy of Economic Development (New Haven: Yale University Press).

Hourwich, I. (1922), Immigration and Labor: The Economic Aspects of European Immiaration to the United States, 2nd Edn. (New York: Huebsch).

James, J. (1978), "The Welfare Effects of the Ante Bellum Tariff: A General Equilibrium Analysis," Explorations in Economic History 15: 231-56.

--- (1984), "The Use of General Equilibrium Analysis in Economic History," Explorations in Economic History 21: 231-53.

Karlstrom, U. (1985), Economic Growth and Miqration During the Industrialization of Sweden: A General Equilibrium Approach (Stockholm: Stockholm School of Economics).

Kelley, A. C. and J. G. Williamson (1971), "Writing History Backwards: Meiji Japan Revisited," Journal of Economic History 31: 729-76.

--- (1973), "Modelling Economic Development and General Equilibrium Histories," American Economic Review 63: 450-8.

--- (1974), Lessons from Japanese Development: An Analytical Economic History (Chicago: University of Chicago Press).

Kelley, A. C., J. G. Williamson and R. J. Cheetham (1972), Dualistic Economic Development: Theory and History (Chicago: University of Chicago Press). Kravis, I. B. (1970), "Trade as a Handmaiden of Growth," Economic Journal 70: 850-72.

Krugman, P. R. and A. Venables (1995), "Globalization and the Inequality of Nations", NBER Working Paper No. 5098, National Bureau of Economic 
Research, Cambridge, MA (April).

Kuznets, S. (1966), Modern Economic Growth (Oxford: Oxford University Press). Lawrence, R. and M. Slaughter (1993), "International Trade and American Wages

in the 1980s: Giant Sucking Sound or Small Hiccup?", Brookings Papers on Economic Activity 2, 161-226.

Lebergott, S. (1964), Manpower and Economic Growth: The American Record Since

1800 (New York: McGraw-Hill).

Lindert, P. H. and J. G. Williamson (1985), "Growth, Equality and History," Explorations in Economic History $22: 341-77$.

Maddison, A. (1982), Phases of Capitalist Development, (New York: Oxford University Press).

-- (1991), Dynamic Forces in Capitalist Development (New York: Oxford University Press).

Mankiw, N. G., D. Romer and D. N. Weil (1992) "A Contribution to the Empirics of Economic Growth," Quarterly Journal of Economics 107: 407-37.

Myrdal, G. (1957), Economic Theory and the Underdeveloped Regions (London). Obstfeld, M. (1994), "International Capital Mobility in the 1990s," International Finance Digcussion Paper No. 472, Board of Governors of the Federal Reserve system (June).

ó Gráda, c. (1994), Ireland 1780-1939: A New Economic History (Oxford: Oxford University Press).

O'Rourke, K. H., A. M. Taylor and J. G. Williamson (1995), "Factor Price Convergence in the Late Nineteenth Century," International Economic Review (forthcoming).

O'Rourke, K. H. and J. G. Williamson (1994), "Late 19th Century Anglo-American Factor Price Convergence: Were Heckscher and Ohlin Right?, "Journal of Economic History 54: 892-916.

--- (1995), "Open Economy Forces and Late 19th Century Swedish Catch-Up: A Quantitative Accounting" and "Education, Globalization and Catch- Up: Scandinavia in the Swedish Mirror," Scandinavian Economic History

Review (forthcoming as Parts I and II).

-- (1996), "Globalization, Education and the European Periphery 1870-1913," 
paper to be presented at the second conference of the FHES, Venice, Italy (January 12-13, 1996).

O'Rourke, K. H., J. G. Williamson, and T. J. Hatton (1994), "Mass Migration, Commodity Market Integration and Real wage Convergence," in T. J. Hatton and J. G. Williamson (eds.), Migration and the International Labor Market, 1850-1939 (London: Rout ledge).

Passell, P. and M. Schmundt (1971), "Pre-Civil War Land Policy and the Growth of Manufacturing," Explorationg in Economic History 9: 35-48.

Passell, P. and G. Wright (1972), "The Effects of pre-Civil War Territorial Expansion on the Price of Slaves," Journal of Political Economy 80: 188202 .

Pope, C. (1972), "The Impact of the Ante Bellum Tariff on Income Distribution," Explorations in Economic History 9: 375-421.

Prados de la Escosura, L., T. Sanchez and J. Oliva (1993), "De Te Fabula Narratur? Growth, Structural Change and Convergence in Europe, 19th and 20th Centuries," Working Paper No. D-93009, Ministerio de Economia y Hacienda, Madrid (December).

Sandberg, L. G. (1979) "The Case of the Impoverished Sophisticate: Human Capital and Swedish Economic Growth before World War I," Journal of Economic History 39: 225-41.

--- (1982), "Ignorance, Poverty and Economic Backwardness in the Early Stages of European Industrialization," Journal of European Economic History 11: 675-97.

Shoven, J. B. and J. Whalley (1992), Applying General Equilibrium (Cambridge: Cambridge University Press).

Simon, J. L. (1989), The Economic Consequences of Immiqration (Cambridge, Mass: Blackwell).

Taylor, A. M., and J. G. Williamson (1994), "Convergence in the Age of Mass Migration," NBER Working Paper No. 4711, National Bureau of Economic Research, Cambridge, MA (April).

Temin, P. (1966), "Labor Scarcity and the Problem of American Industrial Efficiency in the 1850s," Journal of Economic History 26: 277-98. 
Thomas, M. (1987), "General Equilibrium Models and Regearch in Economic History," in A. Field (ed.), The Future of Economic History (Boston: Kluwer-Nijhoff).

Tortella, G. (1994), "Patterns of Economic Retardation and Recovery in SouthWestern Europe in the Nineteenth and Twentieth Centuries," Economic History Review 47: 1-21.

Trefler, D. (1993), "International Factor Price Differences: Leontief Was Right," Journal of Political Economy 101: 961-87.

United States Immigration Commission (1911), Reportg, 61st Congress, 3rd Session (Washington, D.C.: U.S. Government Printing office). Williamson, J. G. (1965), "Regional Inequality and the Process of National Development: A Description of the Patterns," Economic Development and Cultural Change 13,4 , Part II: 1-84.

--- (1974), Late Nineteenth-Century American Development (Cambridge: Cambridge University Press).

-- (1982), "Immigrant-Inequality Trade-offg in the Promised Land: American Growth, Distribution and Immigration Prior to the Quotas," in B. Chiswick (ed.), The Gateway (Washington, D. C.: AEA Press).

--- (1985), Did British Capitalism Breed Inequality? (London: Allen and Unwin).

--- (1990), Coping with City Growth During the British Industrial Revolution (Cambridge: Cambridge University Press).

-- (1991), Inequality, Poverty and History (Oxford: Basil Blackwel1).

--- (1994), "Economic Convergence: Placing Pogt-Famine Ireland in Comparative Perspective," Irish Economic and Social History 20: 1-24.

--- (1995), "The Evolution of Global Labor Markets Since 1830: Background Evidence and Hypotheses," Explorations in Economic History 32: 141-96. Williamson, J. G. and P. H. Lindert (1980), American Inequality: A Macroeconomic History (New York: Academic Press). Wood, A. (1994), North-South Trade, Employment, and Inequality: Changing Fortunes in a skill-Driven World (Oxford: Clarendon Press). Wright, G. (1986), old South, New South (New York: Basic Books). 
--- (1990), "The Origins of American Industrial Success, 1879-1940," American Economic Review 80: 651-68.

zevin, R. B. (1992), "Are World Financial Markets More Open? If so why and With what Effects?" in T. Banuri and J. Schor (eds.), Financial openness and National Autonomy (Oxford: Oxford University Press). 
Table 1

Coefficients of Variation of Real Wages 1854-1939

\begin{tabular}{|c|c|c|c|c|c|c|c|c|}
\hline & \multicolumn{3}{|c|}{ Full Sample } & \multicolumn{3}{|c|}{$\begin{array}{l}\text { Full Sample Less } \\
\text { North America }\end{array}$} & \multicolumn{2}{|c|}{$\begin{array}{c}\text { Full Sample Less } \\
\text { North America } \\
\text { and Iberia }\end{array}$} \\
\hline & $\mathrm{C}(\mathbf{1 3})$ & $\mathrm{C}(17)$ & $C(16)$ & $\mathrm{C}(12)$ & $\mathrm{C}(\mathbf{1 5})$ & $\mathrm{C}(14)$ & $\mathrm{C}(\mathbf{1 0})$ & $\mathrm{C}(\mathbf{1 3})$ \\
\hline 1854 & 0.326 & & & 0.308 & & & 0.340 & \\
\hline 1870 & 0.254 & 0.255 & & 0.224 & 0.223 & & 0.229 & 0.232 \\
\hline 1890 & & 0.199 & & & 0.114 & & & 0.102 \\
\hline 1913 & & 0.191 & & & 0.068 & & & 0.039 \\
\hline 1914 & & & 0.103 & & & 0.085 & & $\overline{0} .068$ \\
\hline 1926 & & & 0.148 & & & 0.146 & & 0.138 \\
\hline 1927 & & 0.188 & 0.147 & & 0.186 & 0.142 & & 0.131 \\
\hline 1939 & & 0.285 & & & 0.200 & & & 0.138 \\
\hline
\end{tabular}

Source: Williamson (1995; revised 1996)

Notes: The "full sample" includes the following thirteen countries until 1870: Australia, United States, Belgium, France, Germany, Great Britain, Ireland, Netherlands, Norway, Spain, Sweden, Brazil, and Portugal. In 1870 the following four countries are added to the sample: Argentina, Canada, Denmark, and Italy. Portugal drops from the sample from 1914 to 1926 and then rejoins. The "full sample less North America" excludes Canada and the United States implying that we start with twelve countries and then increase to fifteen in 1870. Again, Portugal drops from the sample between 1914 and 1926. The "full sample less North America and Iberia" excludes the United States, Canada, Spain, and Portugal implying that we start with ten countries and expand to thirteen in 1870 . 
Table 2

Table of Coefficients of Variation of GDP per Worker-Hour $1870-1938$

\begin{tabular}{lcc}
\hline & Full Sample & $\begin{array}{c}\text { Full Sample Less } \\
\text { North America }\end{array}$ \\
\hline 1870 & $\mathrm{C}(\mathbf{1 5 )}$ & $\mathbf{C}(\mathbf{1 3 )})$ \\
1890 & 0.153 & 0.169 \\
1913 & 0.118 & 0.122 \\
1929 & 0.107 & 0.088 \\
1938 & 0.110 & 0.080 \\
\hline
\end{tabular}

Source: Maddison (1991)

Notes: The "full sample" includes Australia, Austria, Belgium, Canada, Denmark, Finland, France, Germany, Italy, Netherlands, Norway, Sweden, Switzerland, UK, and USA. It does not include Japan. The "full sample less North America" drops Cananda and the US from the sample. 
Table 3

The Estimated Rate of Convergence $(\lambda)$

1854-1939

\begin{tabular}{lcccccc}
\hline \multirow{2}{*}{ Epoch } & \multicolumn{3}{c}{ Real Wages } & & \multicolumn{2}{c}{ GDP per Worker Hour } \\
\cline { 2 - 3 } & $\begin{array}{c}\text { Full } \\
\text { Sample }\end{array}$ & $\begin{array}{c}\text { Less North } \\
\text { America }\end{array}$ & $\begin{array}{c}\text { Less Iberia \& } \\
\text { North America }\end{array}$ & & $\begin{array}{c}\text { Full } \\
\text { Sample }\end{array}$ & $\begin{array}{c}\text { Less North } \\
\text { America }\end{array}$ \\
\hline & & & & & \\
$1854-1870$ & +0.005 & +0.006 & +0.004 & & - \\
$1870-1890$ & +0.012 & +0.020 & +0.021 & & +0.004 & +0.005 \\
$1890-1913$ & +0.008 & +0.017 & +0.033 & & +0.007 & +0.011 \\
& & & -0.030 & & - & - \\
$1914-1926$ & -0.011 & -0.016 & -0.001 & & - & - \\
$1927-1939$ & -0.003 & +0.002 & - & & +0.002 & +0.005 \\
$1913-1929$ & - & - & - & +0.019 & +0.024 \\
$1929-1938$ & - & - & & & \\
\hline
\end{tabular}

Source: Data underlying Tables 1 and 2.

Notes: The rate of convergence is $\lambda=1 / t \ln (\hat{\beta}+1)$, where $\hat{\beta}$ is the coefficient in convergence equation on log of initial real wages or GDP per worker-hour and $\underline{t}$ is the time span. 
Table 4

Conditional Convergence for the Late 19th Century:

Adding Schooling

\section{A. Convergence Regressions:}

\begin{tabular}{|c|c|c|c|c|c|}
\hline \multirow[t]{2}{*}{ Sample } & \multicolumn{2}{|c|}{ Coefficients on: } & \multirow[b]{2}{*}{$\mathbf{R}^{2}$} & \multirow[b]{2}{*}{$\mathbf{N}$} & \multirow[b]{2}{*}{$\lambda$} \\
\hline & $\begin{array}{c}\log \\
1870 \text { value }\end{array}$ & $\begin{array}{l}\log \text { schooling } \\
\text { variable }\end{array}$ & & & \\
\hline \multicolumn{6}{|c|}{ A.1 Using Enrollment Rate Estimates: } \\
\hline $1870-1913$, real wage & $\begin{array}{c}-0.534 * \\
(3.186)\end{array}$ & $\begin{array}{l}0.349 * * * \\
(1.894)\end{array}$ & 0.45 & 16 & 0.018 \\
\hline 1870-1913, GDP per worker & $\begin{array}{c}-0.263^{* *} \\
(2.660)\end{array}$ & $\begin{array}{c}0.095 \\
(1.339)\end{array}$ & 0.37 & $\begin{array}{r}15 \\
-\end{array}$ & 0.007 \\
\hline \multicolumn{6}{|c|}{ A.2 Using Literacy Rate Estimates: } \\
\hline $1870-1913$, real wage & $\begin{array}{r}-0.512 \\
(3.541)\end{array}$ & $\begin{array}{c}0.531 * * \\
(2.676)\end{array}$ & 0.55 & 16 & 0.017 \\
\hline 1870-1913, GDP per worker & $\begin{array}{c}-0.201 * * \\
(2.159)\end{array}$ & $\begin{array}{c}0.063 \\
(0.357)\end{array}$ & 0.29 & 15 & 0.005 \\
\hline
\end{tabular}

Notes: $\mathrm{t}$-statistics in parentheses and ${ }^{*}=$ significance at $1 \%,^{* *}=5 \%$, and ${ }^{* *}=10 \%$. See text on sample.

B. Convergence Impact:

\begin{tabular}{lcc}
\hline \multirow{2}{*}{ Country } & \multicolumn{2}{c}{ Real Wage Growth Using: } \\
\cline { 2 - 3 } & Enrollment & Literacy \\
\hline Argentina & all & all \\
Australia & none & none \\
Belgium & none & none \\
Canada & 21 & 13 \\
Denmark & 27 & 40 \\
France & none & none \\
Germany & none & none \\
Great Britain & 87 & none \\
Ireland & none & all \\
Italy & 84 & all \\
Netherlands & none & none \\
Norway & 25 & 57 \\
Portugal & 61 & 75 \\
Spain & 11 & 59 \\
Sweden & 14 & 31 \\
USA & 65 & 27 \\
\hline
\end{tabular}


Notes:

The following equation underlies the results given above in Panel B:

$$
(y-\bar{y})-\beta 1 *(w-\bar{w})=\beta 2 *(e-\bar{e})+\epsilon
$$

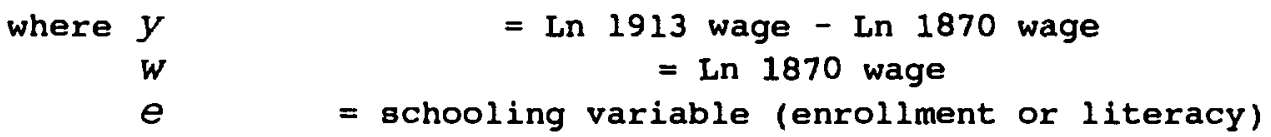

$\beta 1$ is the coefficient on In 1870 wage in the regression of wage growth on initial wage and enrollment literacy (Panel A.1 above) or (Panel A.2 above). $\beta_{2}$ is the coefficient on the schooling variable in the same regression. The list of countries in each regression sample is given in Panel B with the country-specific results. The left side of the equation represents residual above or below average growth in wages net of the initial wage level, which is assumed to capture open economy effects. The right side is a calculation of the amount of wage growth due to above or below average levels of the education variable. By dividing the right side by the left side, we obtain the percentage of above or below average "residual" growth in wages attributable to above or below average levels of enrollment or literacy. 
Figure 1

Real Wage Dispersion 1854-1913

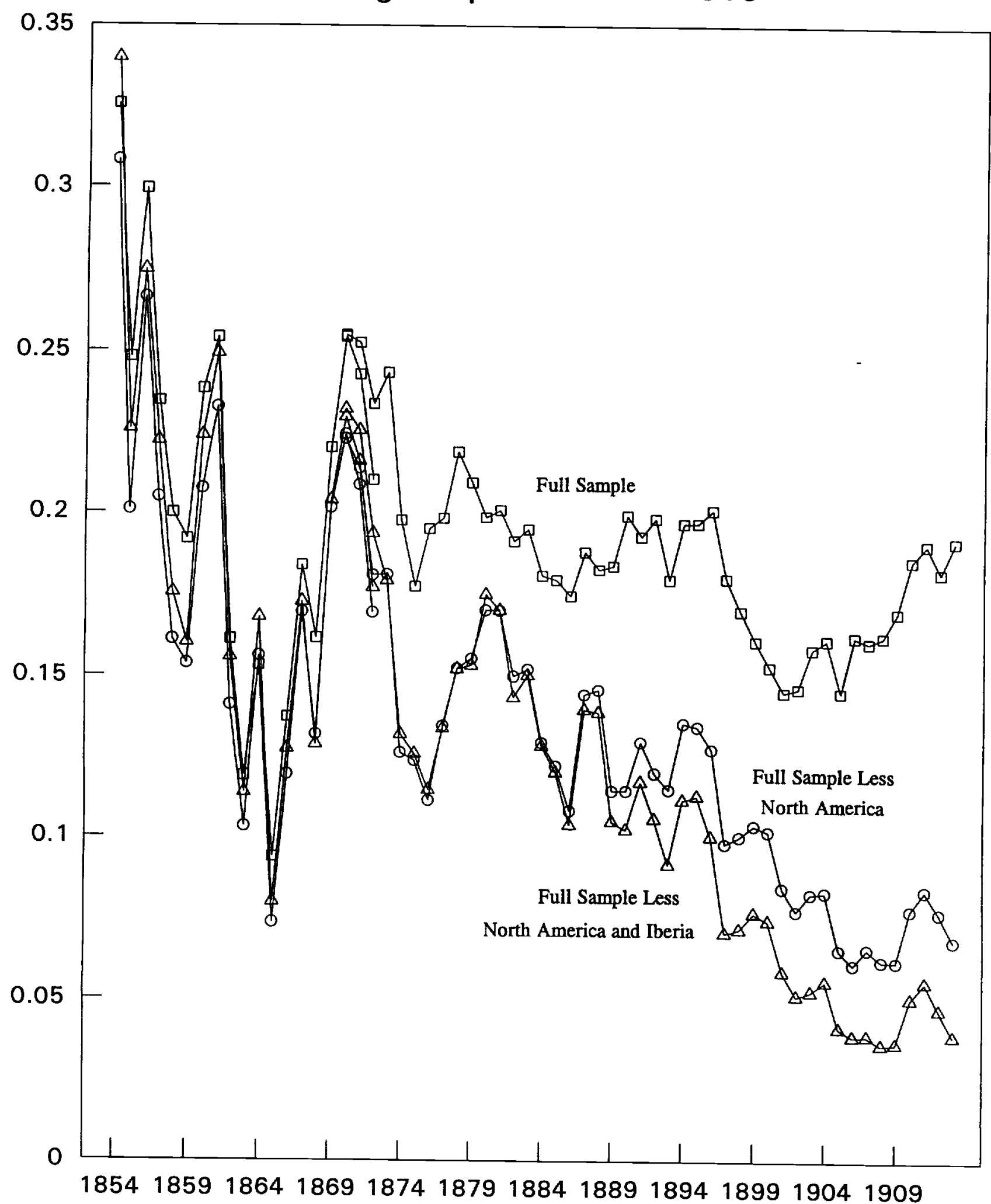

Source: Williamson (1995, Table A2.1; revised 1996) 
Figure 2

Real Wage Dispersion 1914-1939

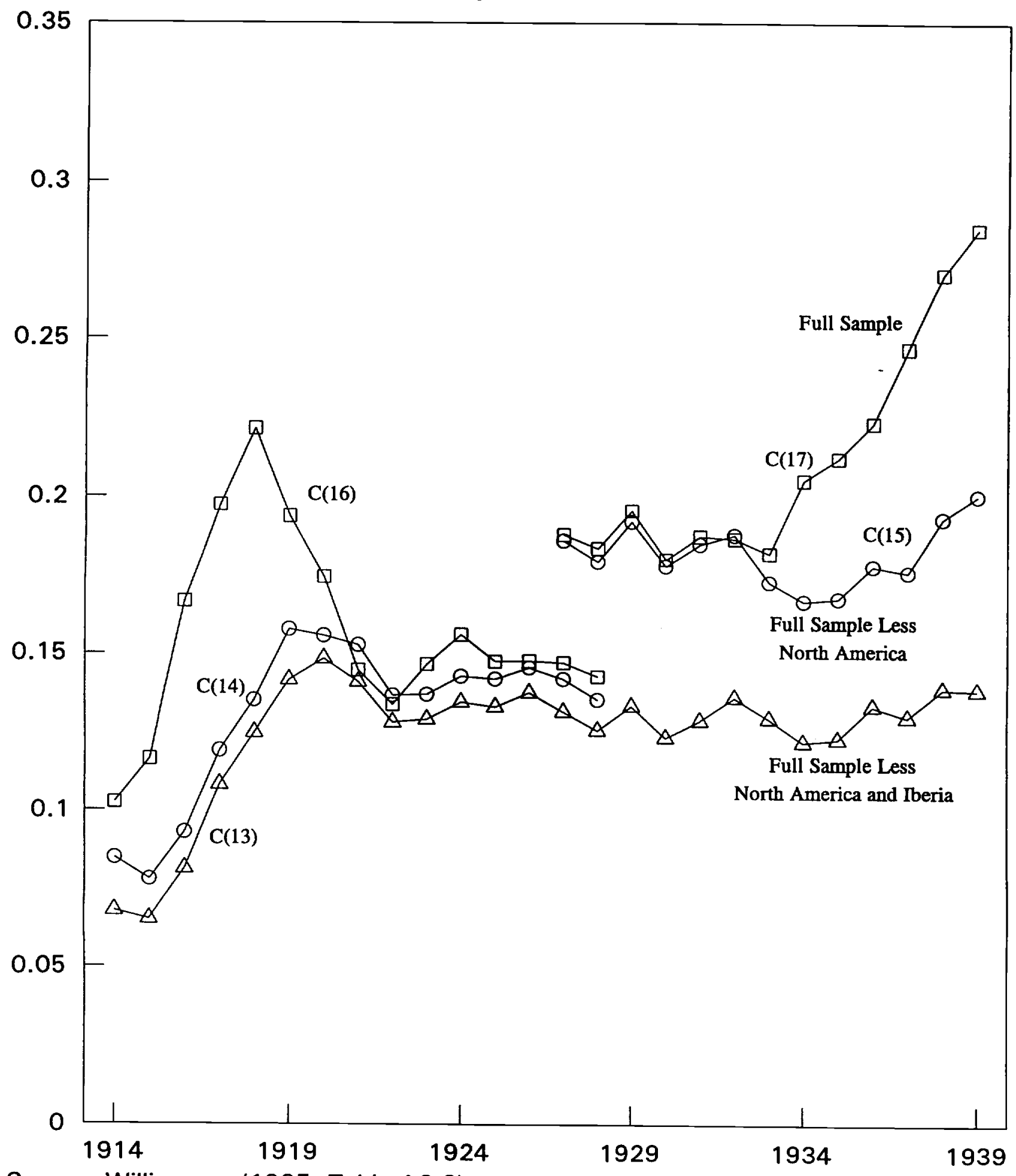

Source: Williamson (1995, Table A2.2)

$C(14)$ and $C(16)$ exclude Portugal which enters in 1927 giving rise to series $C(15)$ and $C(17)$. 
Figure 3

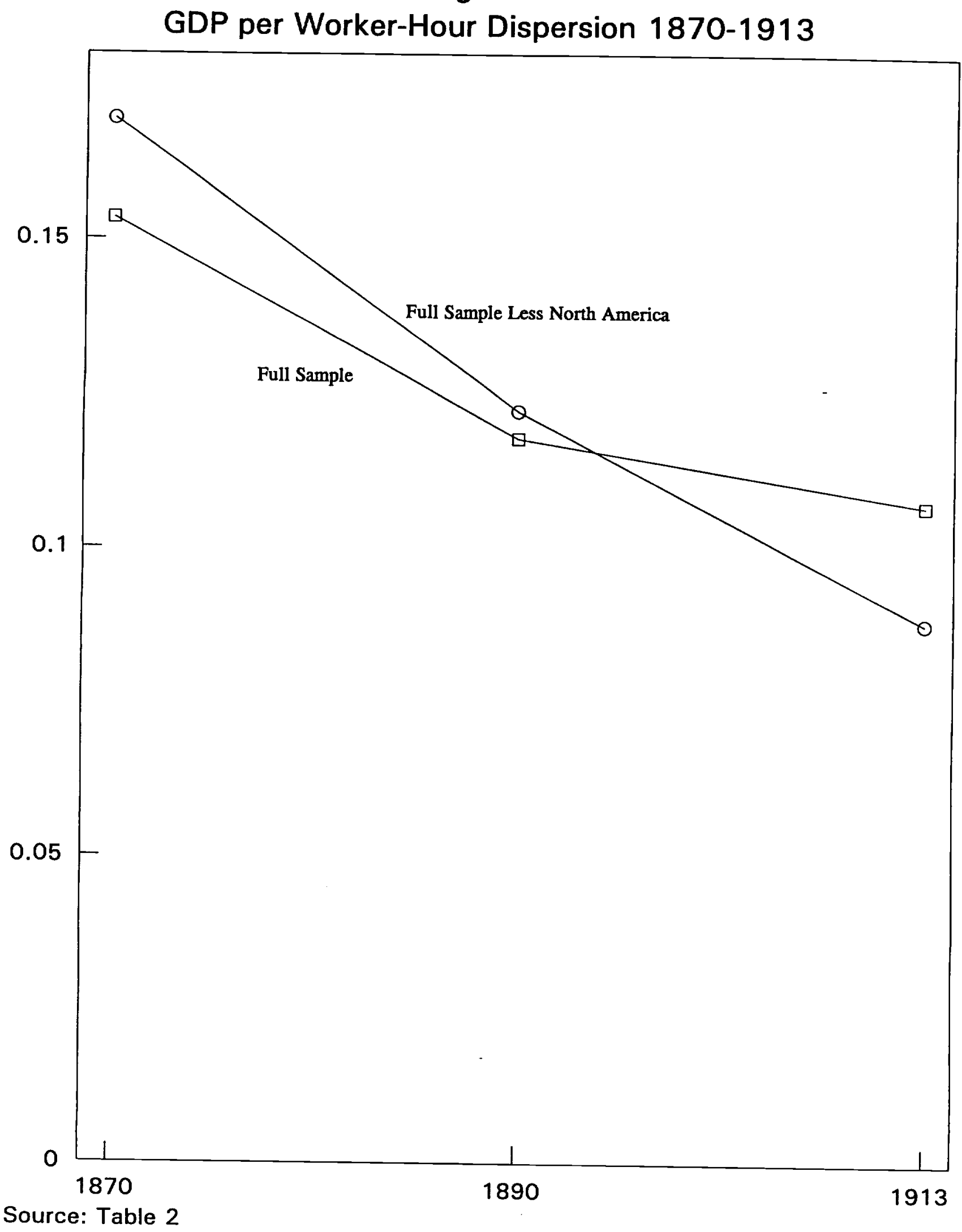


Figure 4

GDP per Worker-Hour Dispersion 1913-1938

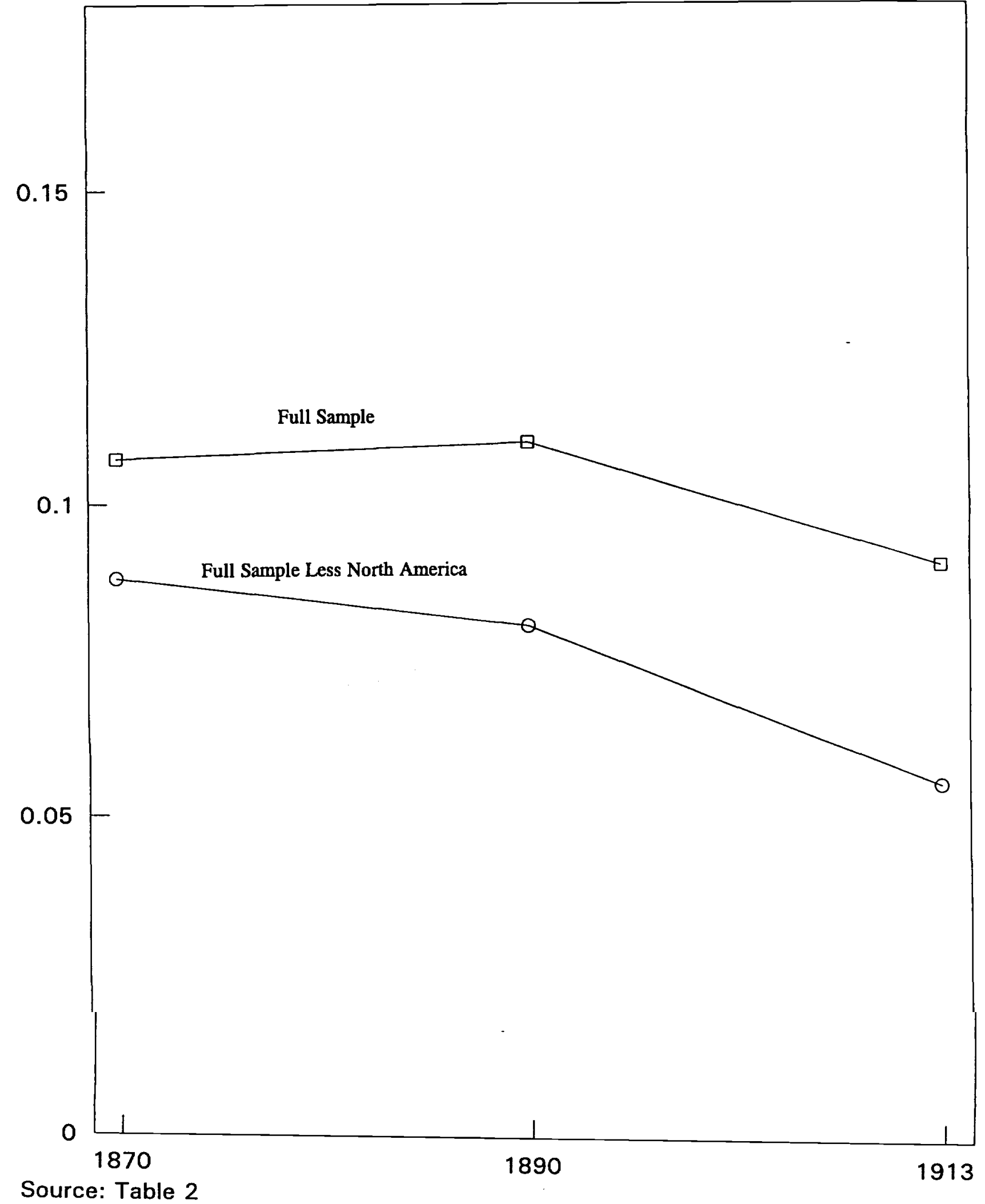

